\title{
FCRL1 Gene
}

National Cancer Institute

\section{Source}

National Cancer Institute. FCRL1 Gene. NCI Thesaurus. Code C117128.

This gene may be involved in B-cell function. 